\title{
Zinc supplementation during in vitro maturation increases the production efficiency of cloned pigs
}

\author{
Yubyeol JEON ${ }^{1,4)}$, Junchul David YOON ${ }^{1}$, Lian $\mathrm{CAI}^{1}{ }^{1}$, Seon-Ung HWANG ${ }^{1}$, Eunhye $\mathrm{KIM}^{1}$, \\ Eunsong LEE"), Eui Bae JEUNG ${ }^{3)}$, Sang-Hwan HYUN ${ }^{1)}$ and Woo Suk HWANG ${ }^{4)}$ \\ 1) Laboratory of Veterinary Embryology and Biotechnology (VETEMBIO), Veterinary Medical Center and College of \\ Veterinary Medicine, Chungbuk National University, Cheongju 28644, Chungbuk, Republic of Korea \\ 2) Laboratory of Theriogenology, College of Veterinary Medicine, Kangwon National University, Chuncheon 24341, \\ Kangwon, Republic of Korea \\ 3) Laboratory of Veterinary Biochemistry and Molecular Biology, College of Veterinary Medicine, Chungbuk National \\ University, Cheongju 28644, Chungbuk, Republic of Korea \\ 4) Sooam Biotech Research Foundation, Guro-gu 08359, Seoul, Republic of Korea
}

\begin{abstract}
Zinc supplementation $(0.8 \mu \mathrm{g} / \mathrm{ml})$ in in vitro maturation (IVM) medium significantly enhances oocyte quality. In this study, we compared the development of somatic cell nuclear transfer (SCNT) embryos produced from conventional IVM (control) and zinc-supplemented IVM oocytes. A total of 1206 and 890 SCNT embryos were produced using control and zinc-supplemented oocytes, respectively, and then were transferred to 11 and 8 recipients, respectively. Five control recipients and three zinc-supplemented recipients became pregnant. Two live piglets and eight mummies were born from two control recipients, and ten live piglets and six stillborn piglets were born from three zinc-supplemented recipients. The production efficiency significantly increased in the zinc-supplemented group $(0.33 \% v s .3 .02 \%)$. This report suggests that zinc supplementation in IVM medium improved the production efficiency of cloned pigs.
\end{abstract}

Keywords: Cloning efficiency, In vitro maturation (IVM), Porcine, Somatic cell nuclear transfer (SCNT), Zinc

(J. Reprod. Dev. 62: 635-638, 2016)

$\mathbf{T}$ ransgenic (TG) cloned pigs have recently become essential in biomedical research [1]. For example, TG cloned pigs have been used in xenotransplantation to generate organ grafts [2,3], as human disease models to study etiology and therapy $[4,5]$, and as living bioreactors to produce valuable proteins for medical applications [6].

Production of TG cloned animals requires advanced reproductive and genetic engineering technologies. However, until recently porcine embryology was one of the least developed and most frustrating fields in reproductive research involving domestic animals [7]. Despite significant improvements in in vitro embryo production for porcine embryology, the development of in vitro-produced embryos remains suboptimal [8-10]. Porcine oocytes and embryos are sensitive to physical and chemical factors used in vitro [11]. Therefore, modified in vitro production systems that more closely mimic the in vivo microenvironment are required to improve the development of porcine embryos. In a previous report, zinc supplementation at a normal body fluid concentration $(0.8 \mu \mathrm{g} / \mathrm{ml})$ during in vitro maturation (IVM) was shown to have beneficial effects on the embryonic development of parthenogenetic and in vitro-fertilized

Received: May 13, 2016

Accepted: July 15, 2016

Published online in J-STAGE: August 2, 2016

(C)2016 by the Society for Reproduction and Development

Correspondence: SH Hyun (e-mail: shhyun@cbu.ac.kr)

This is an open-access article distributed under the terms of the Creative Commons Attribution Non-Commercial No Derivatives (by-nc-nd) License $<$ http://creativecommons.org/licenses/by-nc-nd/4.0/>.
(IVF) embryos [12]. Zinc supplementation during IVM may also be beneficial for the embryonic development of embryos produced by somatic cell nuclear transfer (SCNT) and the production of cloned pigs. Thus, in this report, we attempted to produce cloned pigs using a modified protocol that included zinc supplementation during IVM to improve the developmental capacity of SCNT embryos in vivo.

A total of 485 cloned embryos were produced to evaluate the effect of zinc supplementation during IVM on SCNT embryo development in vitro. There were no significant differences in the cleavage and blastocyst formation rates between the conventional IVM group (control) and the zinc-supplemented group (Table 1).

A total of 1,206 and 890 cloned embryos were produced using control and zinc-supplemented oocytes, respectively; these were then transferred to 11 and 8 recipients, respectively. Five recipients in the control group became pregnant; three aborted and two delivered two live piglets and eight mummies. Three recipients in the zincsupplemented group became pregnant; all three delivered to produce ten live piglets and six stillborn piglets (Tables 2 and 3 ). The pregnancy rate and pregnancy status were not significantly different; however, zinc supplementation during IVM had a tendency $(\mathrm{P}=0.09)$ to affect pregnancy status (Table 2). As shown in Table 3 , the production efficiency significantly increased in the zinc-supplemented group.

The low efficiency of cloned pig production has been attributed to multiple factors, including oocyte quality, the use of inadequate culture and manipulation media during nuclear transfer, the lack of an efficient activation method, difficulty in achieving genetic modification, and the requirement for a minimum number of fetuses to 
Table 1. Effects of zinc supplementation during IVM on in vitro porcine SCNT embryonic development

\begin{tabular}{lccc}
\hline Group & $\begin{array}{c}\text { No. embryo } \\
\text { cultured* }\end{array}$ & $\begin{array}{c}\text { No. cleaved embryos (\%) at } \\
\text { day 2 }\end{array}$ & $\begin{array}{c}\text { No. blastocyst (\%) } \\
\text { at day 7 }\end{array}$ \\
\hline Control & 252 & $205(80.6 \pm 4.4)$ & $56(22.9 \pm 4.0)$ \\
Zinc & 233 & $180(75.3 \pm 4.8)$ & $59(23.7 \pm 4.7)$ \\
\hline
\end{tabular}

* Eight replicates.

Table 2. Effect of zinc supplement during IVM on pregnancy of surrogates after transfer of porcine SCNT embryos

\begin{tabular}{lccccc}
\hline Group & No. surrogates & $\begin{array}{c}\text { No. transferred } \\
\text { embryos }\end{array}$ & $\begin{array}{c}\text { No. (\%) pregnant surrogates } \\
\text { (Pregnancy rate) }\end{array}$ & \multicolumn{2}{c}{ Full-term pregnancy status (\%) of surrogates ${ }^{\#}$} \\
\cline { 5 - 6 } Control & 11 & 1206 & $5(45.5)$ & Abortion & Parturition \\
Zinc & 8 & 890 & $3(37.5)$ & $0(0)$ & $2(18.2)$ \\
\hline \# $\mathrm{P}=0.09$ & & &
\end{tabular}

Table 3. Effect of zinc supplement during IVM on production of cloned piglets after transfer of porcine SCNT embryos

\begin{tabular}{lccccc}
\hline \multicolumn{1}{c}{ Group } & $\begin{array}{c}\text { No. pregnant } \\
\text { surrogates }\end{array}$ & $\begin{array}{c}\text { No. transferred } \\
\text { embryos }\end{array}$ & Average litter size & No. dead fetuses & $\begin{array}{c}\text { No. live fetuses } \\
\text { (Production efficiency) * }\end{array}$ \\
\hline Control & 5 & 570 & $2.00 \pm 1.76$ & 8 & $2(0.33 \pm 0.20)$ \\
Zinc & 3 & 337 & $5.33 \pm 0.67$ & 6 & $10(3.02 \pm 0.90)$ \\
\hline$* \mathrm{P}<0.05$. & & & & &
\end{tabular}

maintain pregnancy in pigs [13]. To improve the efficiency of cloned pig production, this report focused on improving oocyte quality.

Oocyte maturation is an important step in cloned pig production. Recipient oocytes have a marked effect on blastocyst formation and the development of embryos to term [14]. Cloned pigs can be produced using both in vivo- [15] and in vitro- [2, 16, 17] derived oocytes; however, in vivo-derived oocytes enhance the probability of obtaining cloned offspring. According to Lai and Prather [18], incomplete cytoplasmic maturation of porcine oocytes influences both blastocyst formation and full-term development. Therefore, researchers have attempted to identify an alternative method for enhancing oocyte quality and the developmental ability of embryos produced by SCNT. Kun et al. [19] reported that leptin supplementation of IVM medium may be beneficial, not only for the meiotic maturation potential of oocytes, but also for the subsequent developmental competence of embryos produced by parthenogenetic activation and the cleavage of embryos derived by SCNT. In another study, supplementation with cysteamine and $\beta$-mercaptoethanol to improve SCNT embryo development was attempted; however, a stimulatory effect was not observed [20]. Further, L-carnitine treatment during IVM improved the developmental competence of SCNT embryos [21]. This was probably due to increased cytoplasmic maturation, and the stimulation of nuclear reprogramming via increased transcription factor expression. These studies suggest that improving oocyte quality can be beneficial for the developmental competence of SCNT embryos. However, this effect has been not confirmed by an assessment of in vivo viability.

In this report, zinc supplementation during IVM did not improve in vitro development of SCNT embryos, unlike the effect on PA and IVF embryos. Therefore, it is not clear why zinc supplementation improved the production efficiency of cloned pigs. However, the production efficiency of cloned pigs increased in the group that received zinc supplementation during IVM. The beneficial effects of zinc supplementation during IVM on oocyte maturation and embryonic developmental competence were demonstrated in previous report [12]. Specifically, zinc supplementation during IVM increased intracellular GSH synthesis, reduced ROS levels, and improved transcription factor expression. These factors probably improved the developmental competence of SCNT embryos. Also, zinc is involved in cytoskeleton organization. Abnormal microfilament distributions in oocytes were observed under conditions of zinc insufficiency during IVM [22]. Abnormal microfilament distributions can also influence SCNT embryos. According to Cheng et al. [23], cytoskeleton-associated proteins may be key determinants of early clone development. This suggests a supporting role for cytoplasmic components of oocytes in nuclear reprogramming. Zinc is also an essential factor for normal growth and development [24]. Inadequate zinc supplementation during early development caused developmental arrest and abnormal development in early pregnancy. It is believed that zinc supplementation during IVM supports the development of cloned embryos and maintenance of the minimum number of fetuses required for pregnancy.

In conclusion, the present report shows that zinc supplementation during IVM improved the production efficiency of cloned pigs. However, although the production of cloned pigs was improved by zinc supplementation during IVM, the efficiency was still unsatisfactory. Further study to enable more efficient cloned pig production is needed. 


\section{Methods}

\section{Ethics statement}

This study was carried out in strict accordance with the recommendations of the Guide for the Care and Use of Laboratory Animals of the National Veterinary and Quarantine Service (Anyang, Korea). The protocol was approved by the Committee on the Ethics of Animal Experiments of Chungbuk National University (Cheongju, Korea) (Permit number: CBNUA-584-13-01). All surgery was performed under isoflurane anesthesia, and all efforts were made to minimize suffering.

\section{Oocyte collection and IVM}

Porcine ovaries were obtained from a local slaughterhouse and transported to the laboratory within $2 \mathrm{~h}$ in $0.9 \%(\mathrm{w} / \mathrm{v}) \mathrm{NaCl}$ solution that was supplemented with penicillin-G $(100 \mathrm{IU} / \mathrm{ml})$ and streptomycin sulfate $(100 \mathrm{mg} / \mathrm{l})$ at $30-35^{\circ} \mathrm{C}$. Follicular fluid with oocytes was aspirated from antral follicles (3-6 $\mathrm{mm}$ in diameter) using an 18-gauge needle connected to a $10-\mathrm{ml}$ disposable syringe and collected into a 15-ml centrifuge tube. Cumulus-oocyte complexes (COCs) were recovered under a stereomicroscope, and those with at least three layers of compact cumulus cells and a homogenous cytoplasm were selected for IVM. The selected COCs were washed three times in HEPES-buffered Tyrode's medium containing $0.05 \%$ (w/v) polyvinyl alcohol (TLH-PVA), and transferred to $500 \mu$ of tissue culture medium 199 (Invitrogen, Carlsbad, CA, USA) supplemented with $0.8 \mu \mathrm{g} / \mathrm{ml}$ zinc (zinc supplemented group only), $0.6 \mathrm{mM}$ cysteine, $0.91 \mathrm{mM}$ sodium pyruvate, $10 \mathrm{ng} / \mathrm{ml}$ epidermal growth factor, 75 $\mu \mathrm{g} / \mathrm{ml}$ kanamycin, $1 \mu \mathrm{g} / \mathrm{ml}$ insulin, and $10 \%(\mathrm{v} / \mathrm{v})$ pig follicular fluid. The concentration of zinc was set at $0.8 \mu \mathrm{g} / \mathrm{ml}$ in accordance with previous report [12]. For maturation, the selected COCs were washed three times in the above described tissue culture medium 199 (IVM medium) containing hormone supplements $(10 \mathrm{IU} / \mathrm{ml}$ equine chorionic gonadotropin and $10 \mathrm{IU} / \mathrm{ml}$ human chorionic gonadotropin [Intervet, Boxmeer, the Netherlands]), and approximately 50-60 oocytes were transferred to each well of a 4-well Nunc dish (Roskilde, Denmark) containing $500 \mu \mathrm{l}$ of culture medium and equilibrated for at least $2 \mathrm{~h}$ with $5 \% \mathrm{CO}_{2}$ at $39^{\circ} \mathrm{C}$ in a humidified atmosphere. After $22 \mathrm{~h}$ of maturation with hormones, the COCs were washed twice and cultured in hormone-free IVM medium for an additional 18-20 h.

\section{Preparation of donor cells}

Fetal fibroblasts were derived and cultured as described previously [25]. Briefly, a pig fetus (Landrace $\times$ Duroc crossbreed) at embryonic day 40 was isolated from the uterus of a female pig. The tissues of the fetus were cut into $0.5-\mathrm{mm}^{2}$ pieces and cultured in a $100-\mathrm{mm}$ culture dish. Cells were grown at $37^{\circ} \mathrm{C}$ in an atmosphere of $5 \% \mathrm{CO}_{2}$ in Dulbecco's modified Eagle's medium (DMEM) containing $4.5 \mathrm{~g} / 1$ glucose (Gibco BRL, Grand Island, NY, USA) and supplemented with fetal bovine serum $(10 \%)$, penicillin $(100 \mathrm{U} / \mathrm{ml})$, and streptomycin $(100 \mu \mathrm{g} / \mathrm{ml})$. The adherent cells were subcultured. The fetal fibroblasts were frozen and kept at $-150^{\circ} \mathrm{C}$ until SCNT. Prior to SCNT, the cells were thawed and cultured in above described DMEM for 3-4 days until they reached $80 \%$ confluence. Adherent cells (passage 7 10) were treated with trypsin for $\sim 1$ min and used for SCNT.

\section{Micromanipulation for SCNT, fusion, and activation}

After 40-42 h of IVM, denuded oocytes were incubated for $5 \mathrm{~min}$ in manipulation medium (calcium-free TLH containing $0.2 \%$ bovine serum albumin [TLH-BSA]) containing $5 \mu \mathrm{g} / \mathrm{ml}$ Hoechst 33342, washed twice with fresh manipulation medium, and transferred to a drop of manipulation medium containing $5 \mu \mathrm{g} / \mathrm{ml}$ cytochalasin B. The oocytes were enucleated by aspirating the polar body and MII chromosomes using a 16- $\mu \mathrm{m}$ glass pipette (Humagen, Charlottesville, VA, USA). After enucleation, a trypsinized fetal fibroblast of 14-15 $\mu \mathrm{m}$ with a smooth cell surface was transferred to the perivitelline space of the enucleated oocyte. The couplets were equilibrated with $280 \mathrm{mM}$ mannitol solution containing $0.001 \mathrm{mM} \mathrm{CaCl}_{2}$ and 0.05 $\mathrm{mM} \mathrm{MgSO}_{4}$ for 2-3 min and then transferred to a fusion chamber containing two electrodes overlaid with $280 \mathrm{mM}$ mannitol solution. Membrane fusion was induced by applying an alternating current field of $2 \mathrm{~V}$ cycling at $1 \mathrm{MHz}$ for $2 \mathrm{sec}$, followed by two pulses of $160 \mathrm{~V} / \mathrm{mm}$ direct current for $60 \mu \mathrm{sec}$ using a cell fusion generator (LF201; Nepa Gene, Chiba, Japan). The activation was performed simultaneously with the fusion. After fusion, the couplets were washed 3-4 times with TLH-BSA. The oocytes were examined after $30 \mathrm{~min}$, and fused, normally shaped oocytes were collected.

\section{In vitro embryo culture (IVC) and embryo evaluation}

The collected SCNT embryos were washed three times with IVC medium (PZM 3 ) and cultured in 30- $\mu$ l microdrops of IVC medium. Embryos in culture medium were covered with pre-warmed mineral oil and incubated at $39^{\circ} \mathrm{C}$ for 7 days under a humidified atmosphere of $5 \% \mathrm{O}_{2}, 5 \% \mathrm{CO}_{2}$, and $90 \% \mathrm{~N}_{2}$. The day when SCNT were performed was designated as day 0 . The embryos were evaluated under a stereomicroscope for cleavage on day 2. Blastocyst formation was assessed on day 7 .

\section{Embryo transfer}

At $4 \mathrm{~h}$ post-activation, SCNT embryos were transferred to naturally cycling Landrace $\times$ Duroc crossbreed gilts on the first day of standing estrus. A midventral laparotomy was performed under general anesthesia using isoflurane. The reproductive tract was exposed, and the SCNT embryos (100-120 embryos per recipient) were transferred into an oviduct at the ampullary isthmic junction. Pregnancy was diagnosed on day 30 and was checked every 2-4 weeks by ultrasonography. If fetal echoes did not correspond with the gestational age of the fetuses and if signs of fetal absorption, such as small vesicles without any detectable fetuses, were observed, an abortion was considered to have occurred. Each of the cloned piglets was delivered naturally.

\section{Statistical analysis}

Data related to the rates of cleavage, blastocyst formation, litter size, and production efficiency are shown as mean \pm SEM and were compared by Student's $t$-test. Data related to pregnancy rate and pregnancy status were analyzed using chi-square tests. Statistical differences at $\mathrm{P}<0.05$ were considered significant.

\section{Acknowledgements}

This work was supported, in part, by a grant from the "Coop- 
erative Research Program for Agriculture Science \& Technology Development (Project No. PJ011288, PJ011077)", the "Ministry of Trade, Industry \& Energy (MOTIE), Korea Institute for Advancement of Technology (KIAT) through the Leading Industry Development for Economic Region (Project No. R0004357)" and "Korea Institute of Planning and Evaluation for Technology in Food, Agriculture, Forestry and Fisheries (IPET) through Advanced Production Technology Development Program, funded by Ministry of Agriculture, Food and Rural Affairs (MAFRA) (Grant number: 115103-02)", Republic of Korea.

\section{References}

1. Prather RS, Lorson M, Ross JW, Whyte JJ, Walters E. Genetically engineered pig models for human diseases. Annu Rev Anim Biosci 2013; 1: 203-219. [Medline] [CrossRef]

2. Dai Y, Vaught TD, Boone J, Chen SH, Phelps CJ, Ball S, Monahan JA, Jobst PM, McCreath KJ, Lamborn AE, Cowell-Lucero JL, Wells KD, Colman A, Polejaeva IA, Ayares DL. Targeted disruption of the alpha1,3-galactosyltransferase gene in cloned pigs. Nat Biotechnol 2002; 20: 251-255. [Medline] [CrossRef]

3. Prather RS, Hawley RJ, Carter DB, Lai L, Greenstein JL. Transgenic swine for biomedicine and agriculture. Theriogenology 2003; 59: 115-123. [Medline] [CrossRef]

4. Fan N, Lai L. Genetically modified pig models for human diseases. J Genet Genomics 2013; 40: 67-73. [Medline] [CrossRef]

5. Wolf E, Braun-Reichhart C, Streckel E, Renner S. Genetically engineered pig models for diabetes research. Transgenic Res 2014; 23: 27-38. [Medline]

6. Park JK, Lee YK, Lee P, Chung HJ, Kim S, Lee HG, Seo MK, Han JH, Park CG, Kim HT, Kim YK, Min KS, Kim JH, Lee HT, Chang WK. Recombinant human erythropoietin produced in milk of transgenic pigs. J Biotechnol 2006; 122: 362-371. [Medline] [CrossRef]

7. Vajta G, Zhang Y, Macháty Z. Somatic cell nuclear transfer in pigs: recent achievements and future possibilities. Reprod Fertil Dev 2007; 19: 403-423. [Medline] [CrossRef]

8. Macháty Z, Day BN, Prather RS. Development of early porcine embryos in vitro and in vivo. Biol Reprod 1998; 59: 451-455. [Medline] [CrossRef]

9. Papaioannou VE, Ebert KM. The preimplantation pig embryo: cell number and allocation to trophectoderm and inner cell mass of the blastocyst in vivo and in vitro. Development 1988; 102: 793-803. [Medline]

10. Pollard JW, Plante C, Leibo SP. Comparison of development of pig zygotes and embryos in simple and complex culture media. J Reprod Fertil 1995; 103: 331-337. [Medline] [CrossRef]

11. Nagashima H, Kashiwazaki N, Ashman RJ, Grupen CG, Nottle MB. Cryopreservation of porcine embryos. Nature 1995; 374: 416. [Medline] [CrossRef]
12. Jeon Y, Yoon JD, Cai L, Hwang SU, Kim E, Zheng Z, Lee E, Kim DY, Hyun SH. Supplementation of zinc on oocyte in vitro maturation improves preimplatation embryonic development in pigs. Theriogenology 2014; 82: 866-874. [Medline] [CrossRef]

13. Walker SC, Shin T, Zaunbrecher GM, Romano JE, Johnson GA, Bazer FW, Piedrahita JA. A highly efficient method for porcine cloning by nuclear transfer using in vitro-matured oocytes. Cloning Stem Cells 2002; 4: 105-112. [Medline] [CrossRef]

14. Fulka J Jr, Fulka H. Somatic cell nuclear transfer (SCNT) in mammals: the cytoplast and its reprogramming activities. Adv Exp Med Biol 2007; 591: 93-102. [Medline] [CrossRef]

15. Polejaeva IA, Chen SH, Vaught TD, Page RL, Mullins J, Ball S, Dai Y, Boone J, Walker S, Ayares DL, Colman A, Campbell KH. Cloned pigs produced by nuclear transfer from adult somatic cells. Nature 2000; 407: 86-90. [Medline] [CrossRef]

16. Betthauser J, Forsberg E, Augenstein M, Childs L, Eilertsen K, Enos J, Forsythe T, Golueke P, Jurgella G, Koppang R, Lesmeister T, Mallon K, Mell G, Misica P, Pace M, Pfister-Genskow M, Strelchenko N, Voelker G, Watt S, Thompson S, Bishop M. Production of cloned pigs from in vitro systems. Nat Biotechnol 2000; 18: 1055-1059. [Medline] [CrossRef]

17. Lai L, Kolber-Simonds D, Park KW, Cheong HT, Greenstein JL, Im GS, Samue M, Bonk A, Rieke A, Day BN, Murphy CN, Carter DB, Hawley RJ, Prather RS Production of alpha-1,3-galactosyltransferase knockout pigs by nuclear transfer cloning. Science 2002; 295: 1089-1092. [Medline] [CrossRef]

18. Lai L, Prather RS. Production of cloned pigs by using somatic cells as donors. Cloning Stem Cells 2003; 5: 233-241. [Medline] [CrossRef]

19. Kun Z, Shaohua W, Yufang M, Yankun L, Hengxi W, Xiuzhu S, Yonghui Z, Yan L, Yunping D, Lei Z, Ning L. Effects of leptin supplementation in in vitro maturation medium on meiotic maturation of oocytes and preimplantation development of parthenogenetic and cloned embryos in pigs. Anim Reprod Sci 2007; 101: 85-96. [Medline] [CrossRef]

20. Song K, Lee E. Modification of maturation condition improves oocyte maturation and in vitro development of somatic cell nuclear transfer pig embryos. J Vet Sci 2007; 8: 81-87. [Medline] [CrossRef]

21. You J, Lee J, Hyun SH, Lee E. L-carnitine treatment during oocyte maturation improves in vitro development of cloned pig embryos by influencing intracellular glutathione synthesis and embryonic gene expression. Theriogenology 2012; 78: 235-243. [Medline] [CrossRef]

22. Jeon Y, Yoon JD, Cai L, Hwang SU, Kim E, Zheng Z, Jeung E, Lee E, Hyun SH. Zinc deficiency during in vitro maturation of porcine oocytes causes meiotic block and developmental failure. Mol Med Rep 2015; 12: 5973-5982. [Medline]

23. Cheng Y, Gaughan J, Midic U, Han Z, Liang CG, Patel BG, Latham KE. System genetics implicates cytoskeletal genes in oocyte control of cloned embryo quality. Genet ics 2013; 193: 877-896. [Medline] [CrossRef]

24. Vallee BL, Falchuk KH. The biochemical basis of zinc physiology. Physiol Rev 1993; 73 79-118. [Medline]

25. Kwak SS, Cheong SA, Jeon Y, Hyun SH. Porcine granulocyte-macrophage colonystimulating factor improves the in vitro development of cloned porcine embryos. $J$ Vet Med Sci 2012; 74: 1095-1102. [Medline] [CrossRef] 